\title{
Biologic Therapies for Giant Cell Arteritis
}

This article was published in the following Dove Press journal:

Biologics: Targets and Therapy

\author{
Robert Harrington* \\ Shamma Ahmad Al Nokhatha* \\ Richard Conway \\ Department of Rheumatology, St. James's \\ Hospital, Dublin, Ireland \\ *These authors contributed equally to \\ this work
}

Correspondence: Richard Conway

Department of Rheumatology, St. James's Hospital, James Street, Dublin 8, Ireland

Tel +353-|4|0372|

Fax $+353-12836099$

Email drrichardconway@gmail.com

\begin{abstract}
Glucocorticoids have been the mainstay of treatment in giant cell arteritis (GCA) for the past 70 years. Conventional synthetic disease-modifying anti-rheumatic drugs (csDMARDs) have largely failed to show significant clinical efficacy or reduction of the glucocorticoid burden in GCA. Tocilizumab is the first biologic to make a substantial impact in GCA treatment. With the current understanding of GCA pathogenesis implicating multiple cytokines, notably interleukin (IL) 6, IL-12, IL-23, IL-1 $\beta$, and the role of janus kinases (JAKs) and the signal transducer and activator of transcription (STAT) pathway in these cytokines, many biologics are currently being investigated in GCA. This review article looks at the existing evidence for biologic agents in GCA. In addition to tocilizumab, the potential role of ustekinumab, abatacept, JAK inhibitors and other promising biologics in GCA are discussed in detail. A treatment algorithm based on the best evidence to date is also presented.
\end{abstract}

Keywords: giant cell arteritis, biologics, glucocorticoids

\section{Introduction}

Giant cell arteritis (GCA) is the most common form of systemic vasculitis globally. GCA affects people older than 50 years of age, with an increased prevalence seen in Caucasian and Northern European populations. ${ }^{1}$ The incidence continues to rise with increasing age with the highest incidence seen in those over 70 years old. ${ }^{2}$ GCA is a vasculitis of medium and large sized arteries. Typical cranial symptoms include headache, scalp tenderness, jaw claudication or occasionally tongue claudication, dry cough or sore throat as a result of pathological inflammation in branches distal to the carotid arteries. ${ }^{3-5}$ Patients may also present with polymyalgia or non-specific systemic features such as weight loss, fever and malaise. Approximately $25 \%$ of GCA patients have severe ischaemic manifestations including stroke and permanent visual loss (mainly due to involvement of the posterior ciliary arteries). ${ }^{6}$ In the longer term, active GCA can lead to aneurysm formation with thoracic aortic aneurysm being characteristic. Reports on the incidence of aortic aneurysm vary but it is thought to occur in $18 \%$ to $33 \%$ of GCA cases, with dissection occurring in $5 \% .^{9-11}$

Glucocorticoids have been the cornerstone of treatment in GCA for the past 70 years but relapses occur in almost $50 \%$ of treated patients. ${ }^{7,12}$ While glucocorticoids can induce clinical remission, high doses and prolonged courses are required to suppress disease activity in GCA. There is a difficult balance between trying to offset the adverse consequences of long-term glucocorticoid use against the risk of GCA relapse. As a result, a successful glucocorticoid sparing agent in GCA has long been sought. Over the years, many disease-modifying anti-rheumatic drugs 
(DMARDs) traditionally used in rheumatoid arthritis (RA) have been trialled in GCA. To date, most DMARDs have shown minimal efficacy. Methotrexate (MTX), the anchor DMARD in RA, demonstrated a modest effect in GCA. This changed dramatically in 2017 when the seminal GiACTA trial demonstrated the efficacy of blocking the interleukin-6 (IL-6) pathway in GCA with tocilizumab. ${ }^{13}$ In this overview, the authors will review the existing evidence base for biologics in GCA and also discuss emerging treatments currently in development.

\section{Pathogenesis}

GCA is characterised by a pathological granulomatous inflammatory infiltrate within the vessel wall. ${ }^{14}$ The current working model in GCA implicates type 1 helper T cells (Th-1) and type 17 helper T cells (Th-17), Figure $1 .{ }^{15}$ It is theorised that the Th-17 pathway is involved in the acute inflammatory phase while Th-1 compounds the inflammatory response in the chronic phase, causing aneurysmal disease and ischaemic complications. ${ }^{16,17}$ Overproduction of pro inflammatory cytokines such as IL-1 $\beta$, IL-6, IL-12, IL-17A, IL-23, interferon- $\gamma$ (IFN- $\gamma$ ) and tumour necrosis factor $\alpha$ (TNF $\alpha$ ) is seen in GCA, and represent potential therapeutic targets. ${ }^{1,4,18}$ Histological specimens from GCA patients have shown that while the Th17 pathway is responsive to glucocorticoids, the Th-1 pathway is not successfully dampened with ongoing intimal hyperplasia and vascular remodelling. ${ }^{19}$ This suggests that glucocorticoids alone are not sufficient to abrogate GCA in the long term and again reiterates the need for new biologic options.

It has been known for the past three decades that the use of glucocorticoids leads to a rapid reduction in IL-6 in GCA patients. ${ }^{20}$ Furthermore, increased levels of IL-6 mRNA expression have been found in the inflamed temporal artery biopsies of active GCA patients. ${ }^{20-22}$ These findings have provided stimulus for investigating IL-6 blockade in the treatment of GCA. The importance of the JAK/STAT pathway in the pathophysiology of GCA has more recently garnered attention. It is postulated that JAK1 and JAK-2 inhibition can downregulate both the Th-17 and Th-1 pathways, notably suppressing the effects of IFN- $\gamma$, IL-12 and IL-23 (the targets of ustekinumab) and IL-6 (the target of tocilizumab). ${ }^{23}$ As a result, JAK inhibitors are currently under investigation in clinical trials for GCA treatment.

\section{Glucocorticoids}

Glucocorticoids have been the cornerstone of GCA treatment for the last 70 years. ${ }^{7}$ They were first utilised in GCA by Horton in 1949 with formal confirmation of their efficacy by Shick in the 1950 s. ${ }^{24,25}$ While managing to induce clinical remission, high doses of prednisolone at $40-60 \mathrm{mg}$ per day, or even higher, are required initially, generally with prolonged use and frequent relapses over the coming 12-24 months. The lasting sequelae of prolonged glucocorticoid use have been the unfortunate price for remission in GCA.

While glucocorticoids are clinically effective, temporal artery biopsies in GCA patients have shown persistent vascular inflammation in $75 \%$ of patients at 6 months and $44 \%$ at 12 months, despite clinical remission. ${ }^{26}$ Glucocorticoids are far from perfect, but to date inducing remission in GCA has been completely reliant on prolonged administration of high glucocorticoid doses. As mentioned already, glucocorticoids drastically reduce IL- 6 levels in GCA patients and this observation was the rationale for IL-6 blockade and the investigation of tocilizumab as a glucocorticoid sparing therapy in GCA. ${ }^{20}$ Currently, glucocorticoids remain the anchor treatment for inducing remission and biologics to date have been proposed as adjunctive glucocorticoid sparing agents.

\section{Methotrexate}

While MTX is the anchor drug used to treat RA, its efficacy in GCA is modest at best. Given its beneficial effect across a broad spectrum of systemic inflammatory diseases and high dose glucocorticoids effect on GCA, it was a logical and intuitive step to trial MTX as a glucocorticoid sparing agent in GCA. Evidence to date has been mixed however. Two randomised control trials (RCTs) showed no effect, while a third trial demonstrated reduced relapse rate and lower glucocorticoid doses with MTX. It must be acknowledged that all three trials were underpowered due to small sample sizes and generally used relatively low doses of methotrexate. ${ }^{29-31}$ A metanalysis of the three studies was performed in an attempt to overcome the power shortcoming. It reported lower relapse rates (hazard ratio 0.65, $\mathrm{p}=0.04$ ), lower cumulative glucocorticoid doses (mean $-842 \mathrm{mg}$ at 48 weeks) and a higher rate of glucocorticoidfree remission (hazard ratio 2.8, $\mathrm{p}=0.001$ ) with MTX. ${ }^{32}$ The results of this meta-analysis can be viewed in two separate lights. On the one hand, it shows efficacy in reducing relapse rates and notably reduces the total exposure to glucocorticoids. On the other hand, the number needed to treat is high, equating to 10 to prevent one cranial relapse. While MTX is generally a well-tolerated and safe medication, like any therapeutic it has associated adverse events which must be weighed against its potential benefit. Based 


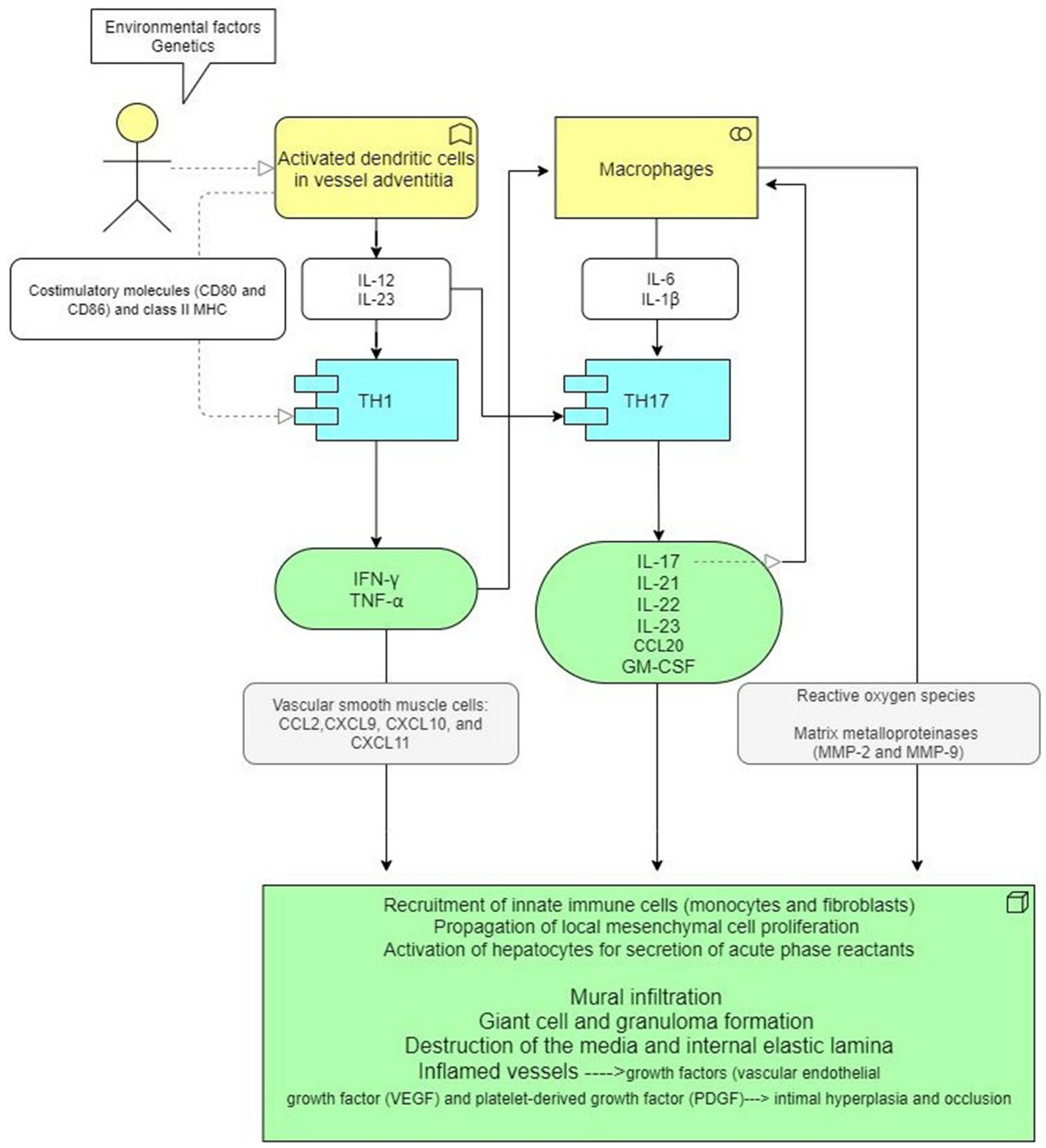

Figure I Current understanding of GCA pathogenesis.

on the available data, the British Society of Rheumatology (BSR) and EULAR guidelines give a conditional recommendation for the use of MTX in GCA. They advise that MTX might be considered for GCA, in combination with a glucocorticoid taper, in patients at high risk of glucocorticoid toxicity or who relapse. ${ }^{33,34}$

\section{Other Non-Biologic} Immunosuppressants in GCA

Other conventional synthetic DMARDs and immunosuppressants have been trialled in GCA. To date, there are small trials and case series in the literature detailing the results of azathioprine, leflunomide, mycophenolate mofetil, 
hydroxychloroquine, dapsone and cyclophosphamide. ${ }^{35-41}$ In one small non-randomised double-blind study, azathioprine showed a significant reduction in mean glucocorticoid dose over the course of 1 year of treatment. ${ }^{42}$ A RCT of hydroxychloroquine did not show evidence of efficacy and 2 open label studies of cyclosporine A did not demonstrate a significant glucocorticoid sparing effect. ${ }^{43-45}$ A French study of 103 patients with glucocorticoid dependent or glucocorticoid resistant GCA demonstrated efficacy with cyclophosphamide treatment. Long-term remission for more than $50 \%$ of patients was achieved with a significant reduction in glucocorticoids and regression of vascular activity on FDGPET. $^{46}$ However, the side effect profile of cyclophosphamide has generally been deemed too severe for consideration as a glucocorticoid sparing agent in this setting. The BSR and EULAR guidelines state that there is at present insufficient evidence to recommend any oral immunosuppressive agent other than MTX in GCA. ${ }^{33,34}$

\section{IL-6 Inhibition - Tocilizumab}

IL-6 plays a key role in the pathogenesis of GCA, and increased levels are detected in both serum and temporal artery biopsies of active patients. ${ }^{20-22}$ IL- 6 has also been demonstrated in the monocytes of GCA patients. ${ }^{47}$ IL-6 concentration is in general closely related to disease activity and there is a strong positive correlation with CRP level. As reduction of IL-6 serum level is associated with reduced disease activity and remission, its inhibition was deemed a potential treatment strategy. ${ }^{22,48,49}$ This must be tempered against the evidence that shows that IL-6 does not stimulate other pro-inflammatory cytokines in an ex-vivo temporal artery biopsy model. ${ }^{50}$ Furthermore, lower levels of IL-6 have been associated with the cranial ischaemic sequelae of $\mathrm{GCA}^{51}$ A 52 week Phase 2 RCT of tocilizumab in 30 patients showed complete remission in $85 \%$ of tocilizumab treated patients vs $40 \%$ of placebo at week 12 and corresponding $85 \%$ relapse-free survival vs $20 \%$ at week $52 .{ }^{52}$ Cumulative glucocorticoid dose and adverse events were both lower in the tocilizumab arm.

The best evidence for the role of IL- 6 inhibition in GCA comes from the Giant-Cell Arteritis Actemra (GiACTA) trial which investigated the potential efficacy of tocilizumab. ${ }^{13}$ It enrolled 251 patients over the age of 50 from July 2013 to April 2015. All included in the trial had active GCA within 3 weeks before baseline with unequivocal evidence of cranial symptoms or polymyalgia and associated increased serum acute phase reactants.
Diagnosis was based on positive temporal artery biopsy or the presence of evidence of large vessel vasculitis on angiography, CT, MRI or PET. The study consisted of 119 newly diagnosed GCA patients and 132 with relapsing GCA. The design was a randomised double-blind placebocontrolled trial with patients divided into 4 groups. Group 1 received tocilizumab $162 \mathrm{mg}$ subcutaneously (SC) every week with 26-week prednisolone taper. Group 2 received tocilizumab $162 \mathrm{mg}$ SC every 2nd week with 26-week prednisolone taper. Group 3 received placebo SC every week with 26-week prednisolone taper. Group 4 received placebo SC every week with 52-week prednisolone taper.

Results were very favourable with both tocilizumab groups achieving far higher rates of sustained remission at the 52-week mark as compared to the placebo groups. Fifty-six percent of patients receiving weekly tocilizumab and $53 \%$ receiving every other week tocilizumab achieved remission as compared to only $14 \%$ and $18 \%$ for patients treated with either the placebo plus 26-week prednisolone taper or the placebo and 52-week prednisolone taper. Furthermore, those receiving tocilizumab experienced less frequent relapses than those receiving placebo plus prednisolone taper. The relapse rate was $23 \%$ and $26 \%$ for those treated with tocilizumab weekly or every other week. Strikingly, the 26-week and 52-week prednisolone and placebo groups experienced relapse rates of $68 \%$ and $49 \%$, respectively.

In summary, the GiACTA trial confirmed the efficacy of tocilizumab in inducing remission, preventing relapses, and reducing the glucocorticoid burden in GCA. One key caveat that must be noted however is that tocilizumab is known to effectively reduce or alter the production of acute phase reactants and in particular CRP. In GiACTA the definition of remission was considered as absence of relapse plus normalisation of CRP which raises concerns over how much of this effect may be due to CRP blunting alone. However, a sensitivity analysis demonstrated that sustained remission rates excluding CRP were 59\% for the tocilizumab weekly group and $55 \%$ for the tocilizumab every other week group. This still compares very favourably to the 26-week and 52-week prednisolone taper groups which each had sustained remission rates of $20 \%$ and $33 \%$, respectively, when CRP was excluded. Even so, demonstration of resolution of vasculitis on imaging or biopsy would help strengthen tocilizumab's case even further. $^{53}$ The results of GiACTA are summarised in Table 1 and Box 1. 
Table I GiACTA Trial Results: Sustained Remission Rates and Flares

\begin{tabular}{|l|l|l|l|}
\hline Group & $\begin{array}{l}\text { Sustained Remission at 52 } \\
\text { Weeks }\end{array}$ & $\begin{array}{l}\text { Flares } \\
\text { Week Steroid Taper }\end{array}$ & $0.23(p<0.00 \mathrm{I})$ \\
\hline Tocilizumab weekly +26 week steroid taper & $56 \%$ & $23 \%$ & $26 \%$ \\
Tocilizumab every 2 weeks +26 week steroid taper & $53 \%$ & $68 \%$ & N/A \\
Placebo +26 week steroid taper & $14 \%$ & $49 \%$ & N/A \\
Placebo +52 week steroid taper & $18 \%$ & $0.00 \mathrm{I})$ \\
\hline
\end{tabular}

\section{Box I Summary of GiACTA Results}

- Better than I in 2 chance of remission at I year with tocilizumab + prednisolone taper

- Less than I in 5 chance of remission at I year with prednisolone alone

- The rates of adverse events did not differ across trial groups, with the exception of neutropenia

Placebo group received approx. twice the cumulative glucocorticoid dose

The BSR and EULAR guidelines both recommend the use of tocilizumab in patients with GCA who have relapsing disease or who have high baseline risk for glucocorticoidrelated adverse events. ${ }^{33,34}$ A RCT of the IL- 6 monoclonal antibody, sirukumab, was terminated early due to a sponsor decision, the limited interpretation of these results was suggestive of efficacy. ${ }^{54}$ An RCT of a second IL- 6 monoclonal antibody, sarilumab, was suspended (NCT03600805).

\section{IL-I 2/IL-23 Inhibition - Ustekinumab}

The current understanding of GCA pathogenesis suggests a role and potential efficacy in dual blockade of IL-12 and IL-23. This has initiated a recent interest in the monoclonal antibody ustekinumab and its potential role in GCA via disruption of Th-1 (IL-12) and Th-17 (IL-23) pathways. ${ }^{55}$ A prospective open-label study of ustekinumab in $25 \mathrm{GCA}$ patients with refractory disease showed promising results. ${ }^{56,57}$ All patients had refractory disease with either an inability to taper prednisolone to an acceptable dose or a history of multiple relapses during prednisolone taper. Those included in the trial had failed a median of one prior glucocorticoid-sparing agent. Ustekinumab proved efficacious in this small study with a reduction in median prednisolone dose from $20 \mathrm{mg}$ to $5 \mathrm{mg}(\mathrm{p}<0.001)$. There was a concordant significant reduction in CRP from $12.9 \mathrm{mg} / \mathrm{L}$ to $6 \mathrm{mg} / \mathrm{L}(\mathrm{p}=0.006)$, despite the reduction in glucocorticoid dose. No patients experienced a flare during treatment and one quarter managed to stop prednisolone completely. CT angiography also showed improvement in radiographic large vessel vasculitis in all patients with complete resolution in $50 \%$ of cases. There were no unexpected adverse events with ustekinumab treatment. Three patients discontinued ustekinumab due to adverse events with two of these patients subsequently developing polymyalgic flares of GCA at 4 and 5 months, respectively, after stopping ustekinumab. While this was an open-label study without a control group, the results were encouraging.

This provided the stimulus for further investigation into the potential efficacy of ustekinumab in GCA. A second prospective, single centre, open-label pilot study was subsequently performed. ${ }^{58}$ This study enrolled both new onset and relapsing GCA patients with active disease. Diagnosis required either a positive temporal artery biopsy or evidence of large vessel vasculitis on imaging. A sample of 20 consecutive patients were initially planned for the study but it was terminated prematurely by the investigators due to a lack of efficacy. While all patients achieved remission within 4 weeks of baseline, only 3 patients $(23 \%)$ achieved the primary outcome of glucocorticoid free-remission at week 52 with normalisation of ESR $(<40 \mathrm{~mm} / \mathrm{hr})$ and CRP $(<10 \mathrm{mg} / \mathrm{L})$ while adhering to the predetermined glucocorticoid taper protocol. Of the 10 patients $(77 \%)$ who failed to achieve this primary outcome, 7 flared after a mean period of 23 weeks and 3-6 ustekinumab injections. The other 3 patients, while not having clinical symptoms of relapse, did not achieve the primary outcome due to elevated inflammatory markers. The authors concluded that ustekinumab in combination with 6 months of prednisolone was not associated with clinically significant rates of sustained disease remission in this cohort of GCA patients.

Important differences exist between these studies in terms of inclusion criteria, glucocorticoid taper, and definitions of treatment success. Given the different findings from these two trials, the results of further studies are awaited, in particular those of an ongoing randomised control trial (NCT03711448). 


\section{TNF Inhibitors}

The stimulus for exploring the role of TNF inhibition in GCA originated from the discovery of high tissue levels of $\mathrm{TNF} \alpha$ in positive temporal artery biopsies. ${ }^{21} \mathrm{RCTs}$ however have failed to demonstrate a benefit of TNF inhibition in GCA. A Phase II randomised, double-blind, placebocontrolled trial examined the potential role of infliximab in GCA patients with new onset disease. It included 44 patients with remission of symptoms and normalisation of ESR after induction with prednisolone $40-60 \mathrm{mg} /$ day. Patients were then randomised to either placebo $(n=16)$ or infliximab $5 \mathrm{mg} / \mathrm{kg}$ infusions $(\mathrm{n}=28)$ at weeks $0,2,6,14,22,30,38$ and 46. Infliximab did not demonstrate a significant increase in the number of relapse-free patients nor did it achieve a significant reduction in cumulative prednisolone dose. Infection risk was also higher in the infliximab group. ${ }^{59}$ Adalimumab also did not demonstrate a benefit in a RCT in GCA. There was no significant difference in remission rates with $59 \%$ in the adalimumab group versus $50 \%$ in the placebo group in remission at week $26 .{ }^{60}$ In contrast, one small RCT of 17 GCA patients treated with etanercept, a soluble TNF receptor fusion protein, displayed encouraging results. Fifty percent of the etanercept group were in glucocorticoid-free remission at 12 months compared with only $12 \%$ in the placebo and prednisolone group. Cumulative prednisolone dose was also significantly lower in the etanercept group. ${ }^{61}$ However, careful consideration must be given to these results on account of the small study size and loss to follow up. On the balance of the available evidence, TNF inhibitors do not appear to be efficacious in GCA.

\section{T-Cell Modulation - Abatacept}

Abatacept, a CTLA-4Ig small molecule fusion protein binds to $\mathrm{CD} 80 / \mathrm{CD} 86$ and dampens T-cell activation. Given the hypothesised role of dual T-lymphocyte pathways, Th- 1 and Th-17, in GCA, abatacept offers a plausible mechanism of action for disease treatment. ${ }^{7}$ In a RCT, abatacept in conjunction with prednisolone demonstrated an increase in relapse-free survival at 12 months from $31 \%$ to $48 \%$ when compared to prednisolone monotherapy. ${ }^{62}$ The median duration of remission was also greater in the abatacept group at 9.9 months versus 3.9 months in the placebo group. The interpretation of the results of this study is complicated by the fact that all patients received abatacept in conjunction with glucocorticoids for the first 12 weeks before patients were randomised to either continuing or stopping abatacept. Furthermore, sample size was small at 41 patients with 20 randomised to placebo and 21 to the abatacept continuation group. Given the modest improvement in outcome, small sample size, complicated trial design and the lack of efficacy of abatacept in a parallel RCT for Takayasu's arteritis, the body of evidence is not substantial enough to confidently declare that abatacept is efficacious as an adjunctive treatment or glucocorticoid sparing agent in GCA. ${ }^{62}$

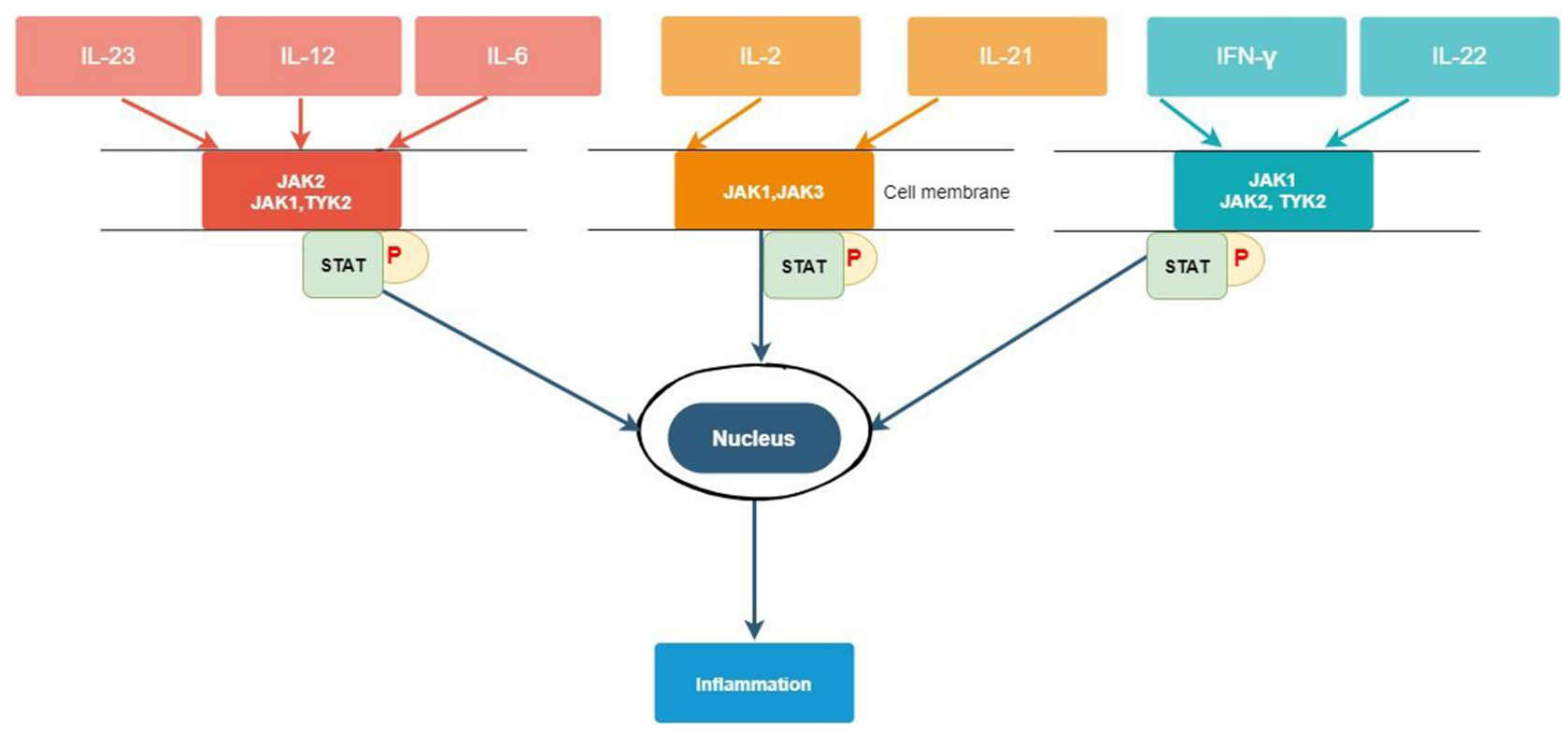

Figure 2 JAK/STAT pathways and implicated cytokines in GCA. 
Table 2 Overview of Biologics in GCA

\begin{tabular}{|c|c|c|c|c|}
\hline Biologic & Target & $\begin{array}{l}\text { Level of } \\
\text { Evidence }\end{array}$ & Study Results & Study Limitations \\
\hline Tocilizumab & IL-6 & 2 RCTs & $\begin{array}{l}\text { Villiger et al }(2016)^{52} \\
30 \text { patients } \\
77 \% \text { new onset } \\
\text { Relapse-free week } 52 \\
85 \% \text { tocilizumab + GC } \\
20 \% \text { GC alone } \\
\text { GiACTA - Stone et al }(2017)^{13} \\
25 \text { I patients } \\
47 \% \text { new onset } \\
\text { Remission week } 52 \\
\text { Tocilizumab weekly + } 26 \text { weeks GC } 56 \% \\
\text { Tocilizumab every } 2 \text { weeks + } 26 \text { weeks GC 53\% } \\
26 \text { weeks GC alone } 14 \% \\
52 \text { weeks GC alone } 18 \%\end{array}$ & $\begin{array}{l}\text { Villiger et al }(2016)^{52} \\
\text { Singe centre and small numbers } \\
\text { Not blinded to CRP results } \\
\text { GC stopped after } 6 \text { months } \\
\text { No discontinuation data } \\
\text { Limited imaging } \\
\text { GIACTA- Stone et al }(2017)^{13} \\
\text { No discontinuation data } \\
\text { Lack of imaging data } \\
\text { Short duration of follow-up } \\
\text { Concern that vascular disease may } \\
\text { progress despite clinical remission }\end{array}$ \\
\hline Sirukumab & IL-6 & RCT & $\begin{array}{l}\text { Schmidt et al }(2020)^{54} \text { Numerically lower rate of flares in } \\
\text { sirukumab group }\end{array}$ & Terminated early \\
\hline Sarilumab & IL-6 & RCT & Commenced but suspended (NCT03600805) & \\
\hline Abatacept & T-cell & RCT & $\begin{array}{l}\text { Langford et al }(2017)^{62} 4 I \text { patients } \\
56 \% \text { new onset } \\
\text { Abatacept induction for all randomised at month } 3 \text { to abatacept + } \\
\text { GC versus GC alone } \\
\text { Relapse-free week } 52 \text { Abatacept + GC } 48 \% \\
\text { GC alone } 31 \%\end{array}$ & $\begin{array}{l}\text { Modest effect } \\
\text { All received abatacept } \\
\text { Abatacept ineffective in } \\
\text { Takayasu's arteritis }\end{array}$ \\
\hline Ustekinumab & $\begin{array}{l}\text { IL- I } 2 / \\
\text { IL-23 }\end{array}$ & Open Label & $\begin{array}{l}\text { Conway et al }(2016,2018)^{17,57} \\
25 \text { patients } \\
\text { All refractory GCA } \\
\text { Median GC dose decreased from } 20 \mathrm{mg} \text { to } 5 \mathrm{mg} \text { at week } 52 \\
\text { No relapses on ustekinumab } \\
\text { Imaging evidence of improvement } \\
\text { Matza et al } \\
13 \text { patients } \\
39 \% \text { new onset } \\
23 \% \text { remission free at week } 52\end{array}$ & $\begin{array}{l}\text { Conway et al(2016, 2018) } \\
\text { Unblinded } \\
\text { No control group } \\
\text { Small numbers } \\
\text { Single centre } \\
\text { Matza et al } \\
\text { Unblinded } \\
\text { No control group } \\
\text { Small numbers } \\
\text { Single centre }\end{array}$ \\
\hline Secukinumab & IL-17 & Case reports & Rotar et al $(2018)^{74}$ Sammut et al $(2018)^{75}$ Effective in 2 cases & Case report data only \\
\hline Adalimumab & TNF- $\alpha$ & RCT & $\begin{array}{l}\text { Seror et al }(2014)^{60} 70 \text { patients } \\
\text { All new onset } \\
\text { Remission week } 26 \\
\text { GC + adalimumab } 59 \% \\
\text { GC alone } 50 \%\end{array}$ & $\begin{array}{l}\text { New-onset patients only } \\
\text { Excluded ischaemic } \\
\text { manifestations }\end{array}$ \\
\hline Infliximab & TNF- $\alpha$ & RCT & $\begin{array}{l}\text { Hoffmann et al }(2007)^{59} 44 \text { patients } \\
\text { All new onset } \\
\text { Relapse-free } 52 \text { weeks } \\
\text { Infliximab + GC } 43 \% \\
\text { GC alone } 50 \%\end{array}$ & $\begin{array}{l}\text { Small numbers } \\
\text { New-onset patients only } \\
\text { Study terminated early }\end{array}$ \\
\hline
\end{tabular}

(Continued) 
Table 2 (Continued).

\begin{tabular}{|c|c|c|c|c|}
\hline Biologic & Target & $\begin{array}{l}\text { Level of } \\
\text { Evidence }\end{array}$ & Study Results & Study Limitations \\
\hline Etanercept & TNF- $\alpha$ & RCT & $\begin{array}{l}\text { Martinez-Taboada et al }(2008)^{61} 17 \text { patients } \\
\text { All in remission on GC with GC-related adverse events } \\
\text { GC remission week } 52 \\
\text { Etanercept }+ \text { GC } 50 \% \\
\text { GC alone } 22 \%\end{array}$ & $\begin{array}{l}\text { Small numbers } \\
\text { High discontinuation rate }-11 / 19 \\
\text { patients }\end{array}$ \\
\hline Anakinra & IL-I $\beta$ & $\begin{array}{l}\text { Case series } \\
\text { Ongoing RCT }\end{array}$ & $\begin{array}{l}\text { Ly et al }(2014)^{70} 3 \text { refractory GCA patients; remission in all } 3 \\
\text { GiAnT (NCT0290273I) }\end{array}$ & Case report data only at present \\
\hline Gevokizumab & IL-I $\beta$ & $\mathrm{RCT}$ & Commenced but cancelled & \\
\hline Rituximab & B-cells & Case reports & $\begin{array}{l}\text { Bhatia et al }(2005)^{68} \text { Mayrbaeurl et al }(2007)^{69} \text { Effective in } 2 \text { refractory } \\
\text { cases }\end{array}$ & Case report data only \\
\hline Baricitinib & JAK & $\begin{array}{l}\text { Open-label } \\
\text { study ongoing }\end{array}$ & (NCT03026504) & \\
\hline Upadacitinib & JAK & RCT ongoing & SELECT-GCA (NCT03725202) & \\
\hline Tofacitinib & JAK & $\begin{array}{l}\text { Laboratory } \\
\text { data only }\end{array}$ & & \\
\hline Mavrilimumab & $\begin{array}{l}\text { GM- } \\
\text { CSF }\end{array}$ & RCT ongoing & $\begin{array}{l}\text { Cid et al }(2020)^{73} \text { Sustained remission at week } 26 \text { in } 83 \% \text { with } \\
\text { mavrilimumab compared to } 50 \% \text { with placebo (NCT038270I8) }\end{array}$ & $\begin{array}{l}\text { Preliminary data, presented, not } \\
\text { published }\end{array}$ \\
\hline
\end{tabular}

\section{JAK Inhibitors}

The JAK/STAT inhibitor tofacitinib, which targets JAK1 and JAK3, has been explored in a basic science model and shown to reduce $\mathrm{T}$ cell accumulation in the vessel wall of a human artery engrafted into immunodeficient mice that were reconstituted with $\mathrm{T}$ cells and monocytes from humans with GCA. ${ }^{63,64}$ This working lab model of vascular inflammation provided encouraging signs for a potential future role of JAK/ STAT pathway inhibition in GCA. Furthermore, our current understanding of cytokine biology suggests that strong inhibition of JAK1 and JAK2 should in theory downregulate the effects of IL-6, IL-12, IL-23 and IFN- $\gamma$, Figure 2. As discussed earlier, tocilizumab inhibits IL-6 while ustekinumab inhibits IL-12 and IL-23. Baricitinib which acts on JAK1 and JAK2 may be able to block the effects of all of these cytokines and therefore be efficacious in treating GCA. Baricitinib is currently being assessed in a Phase II, single institution, openlabel pilot study (NCT03026504) with 15 patients with relapsing GCA currently enrolled. Upadacitinib, a JAK1 and JAK2 inhibitor is also under investigation as a potential treatment in GCA. The SELECT-GCA trial (NCT03725202) is currently enrolling a desired 420 participants in a multicentre, randomised, double-blind, placebo-controlled study over a 4-year period with study completion anticipated for November 2024. To date, although preliminary results from animal models are promising, there is insufficient evidence to advocate JAK inhibitors as glucocorticoid sparing agents in GCA.

\section{B-Cell Depletion - Rituximab}

While GCA is considered a largely T-cell mediated disease, it is known that B lymphocytes have an important role in T-cell activation. Circulating levels of $\mathrm{B}$ cells are generally decreased in active GCA but repopulate after glucocorticoid treatment with one plausible explanation suggesting that this is due to the recruitment of B cells into inflamed vessels. ${ }^{65}$ However, while B cells are present in GCA lesions they are not abundant. ${ }^{65-67}$ There are two case reports demonstrating the efficacy of rituximab in refractory GCA. ${ }^{68,69}$

\section{Anti-IL-I $\beta$ Inhibitors}

Temporal artery biopsies of GCA patients have demonstrated increased expression of IL- $1 \beta$ mRNA and to date, one case series of 3 patients with refractory GCA has shown efficacy with IL-1 $\beta$ blockade with anakinra at a dose of 


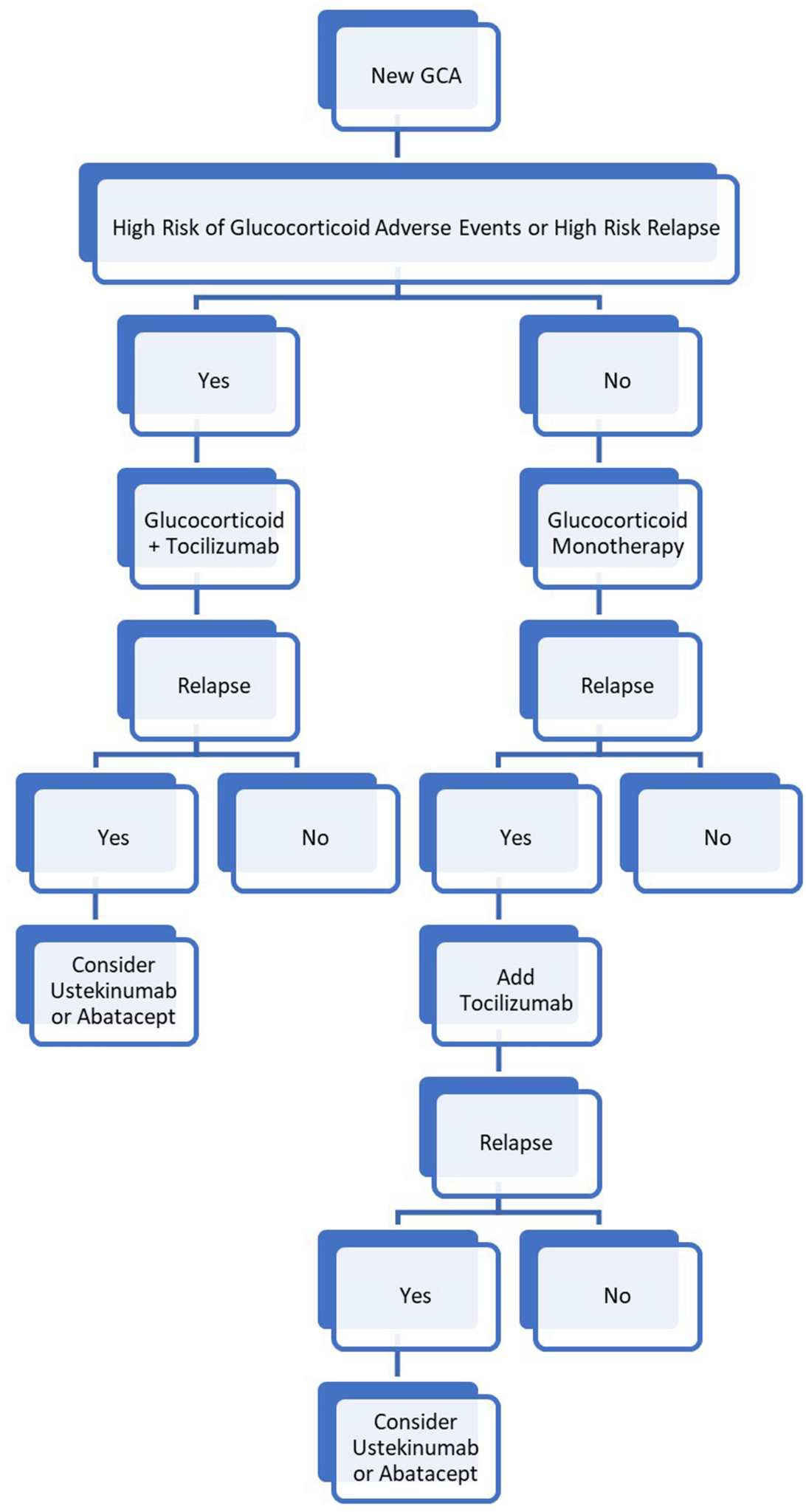

Figure 3 Proposed GCA treatment algorithm.

$100 \mathrm{mg} /$ day. $^{70}$ All 3 patients experienced improvement in symptoms correlating with normalisation of inflammatory markers. Reassuringly, there was also resolution of vascular inflammation on PET/CT for two or these patients. ${ }^{70}$ To investigate the potential efficacy and viability of anakinra as a treatment for GCA, the Giant Cell Arteritis and Anakinra 
Trial (GiAnT) (NCT02902731) was established. The investigators proposed a randomised, multi-centre, double-blind, placebo-control trial of 70 patients randomised to either prednisolone and anakinra or prednisolone and placebo. The study is anticipated to finish by March 2022 . A previous RCT of the IL-1 $\beta$ inhibitor gevokizumab was commenced but subsequently terminated by the sponsor.

\section{GM-CSF Pathway Inhibitors - Mavrilimumab}

The granulocyte macrophage colony stimulating factor (GMCSF) pathway has been shown to be unregulated in GCA biopsies. Mavrilimumab is a monoclonal antibody targeting the GM-CSF receptor currently under investigation for its potential in GCA treatment. Reduction of inflammation in an ex vivo GCA culture model has been demonstrated. ${ }^{71}$ There was also a significant improvement in arterial inflammation compared to control in an in vivo model of vasculitis. It has also been shown in a phase $2 b$ trial in RA that mavrilimumab achieves rapid and sustained reduction in IL- 6 production. ${ }^{72}$ A phase 2 RCT of 70 patients with either new onset or refractory GCA (NCT03827018) is underway. Preliminary results have demonstrated efficacy with $83 \%$ of mavrilimumab treated patients in sustained remission at week 26 compared to $50 \%$ of placebo-treated patients. ${ }^{73}$

\section{IL-I 7 Inhibition - Secukinumab}

IL-17 is a cytokine released by Th17 cells, which are a key part of the pathogenic pathway in GCA. There have been two case reports of patients with psoriatic arthritis and GCA where secukinumab appears to have been beneficial for the maintenance of remission of the GCA. ${ }^{74,75}$ A phase 2 RCT of secukinumab in GCA is currently recruiting patients (NCT03765788).

An overview of biologics suggested for use in GCA is shown in Table 2.

\section{Proposed Treatment Algorithm}

Given the sustained remission rate and the reduction in cumulative prednisolone dose seen in the GiACTA trial, there is a strong argument to recommend combined glucocorticoid and tocilizumab treatment as first line in GCA when there is deemed to be high risk of glucocorticoid adverse events or high risk of relapse with glucocorticoid monotherapy. In refractory cases, the authors of this paper would advocate trial of a second biologic in place of tocilizumab. Potential second-line biologics include ustekinumab or abatacept. Ongoing trials may reshape this guidance in the coming years. A current proposed treatment algorithm is shown in Figure 3.

\section{Conclusion}

Glucocorticoids have been the mainstay of treatment in GCA for the past 70 years and they should remain so for now. Currently, IL-6 blockade with tocilizumab has the best evidence base as an adjunctive treatment in GCA. While ustekinumab, abatacept, JAK inhibitors and IL-1 $\beta$ inhibitors have shown efficacy in small studies, there is still limited evidence for these agents. We make the tentative recommendation that GCA cases refractory to tocilizumab may trial ustekinumab or abatacept. JAK inhibitors and IL-1 $\beta$ inhibitors are currently in trials for GCA which may reshape best guidance on GCA treatment over the next decade.

\section{Ethics and Informed Consent}

This article does not contain any studies with human or animal subjects performed by any of the authors.

\section{Disclosure}

No funding was received for this manuscript. The authors have no conflicts of interest in relation to the current work.

\section{References}

1. Gonzalez-Gay MA, Vazquez-Rodriguez TR, Lopez-Diaz MJ, et al. Epidemiology of giant cell arteritis and polymyalgia rheumatica. Arthritis Rheum. 2009;61:1454-1461. doi:10.1002/art.24459

2. Gonzalez-Gay MA, Miranda-Filloy JA, Lopez-Diaz MJ, et al. Giant cell arteritis in north-western Spain: a 25-year epidemiologic study. Medicine. 2007;86:61-68. doi:10.1097/md.0b013e31803d1764

3. Prior JA, Ranjbar H, Belcher J, et al. Diagnostic delay for giant cell arteritis - a systematic review and meta-analysis. BMC Med. 2017;15:120. doi:10.1186/s12916-017-0871-Z

4. Salvarani C, Cantini F, Boiardi L, Hunder GG. Polymyalgia rheumatica and giant cell arteritis. $N$ Engl J Med. 2002;347:261-271. doi:10.1056/NEJMra011913

5. González-Gay MA, Pina T. Giant cell arteritis and polymyalgia rheumatica: an update. Curr Rheumatol Rep. 2015;17:6. doi:10. 1007/s11926-014-0480-1

6. Gonzalez-Gay MA, Castañeda S, Llorca J. Giant cell arteritis: visual loss is our major concern. $J$ Rheumatol. 2016;43:1458-1461. doi:10.3899/jrheum.160466

7. Low C, Conway R. Current advances in the treatment of giant cell arteritis: the role of biologics. Ther Adv Musculoskelet Dis. 2019. doi:10.1177/1759720X19827222

8. Singh AG, Kermani TA, Crowson CS, et al. Visual manifestations in giant cell arteritis: trend over 5 decades in a population-based cohort. $J$ Rheumatol. 2015;42:309-315. doi:10.3899/jrheum.140188

9. Nuenninghoff DM, Hunder GG, Christianson TJ, et al. Mortality of large-artery complication (aortic aneurysm, aortic dissection, and/or large artery stenosis) in patients with giant cell arteritis: a population-based study over 50 years. Arthritis Rheum. 2003;48:3532-3537. doi:10.1002/art.11480 
10. García-Martínez A, Arguis P, Prieto-González S, et al. Prospective long-term follow-up of a cohort of patients with giant cell arteritis screened for aortic structural damage (aneurysm or dilatation). Ann Rheum Dis. 2014;73:1826-1832. doi:10.1136/annrheumdis-2013-203322

11. Nuenninghoff DM, Hunder GG, Christianson TJ, et al. Incidence and predictors of large artery complication (aortic aneurysm, aortic dissection, and/or large-artery stenosis) in patients with giant cell arteritis: a population-based study over 50 years. Arthritis Rheum. 2003;48:3522-3531. doi:10.1002/art.11353

12. Martinez-Lado L, Calviño-Díaz C, Piñeiro A, et al. Relapses and recurrences in giant cell arteritis: a population-based study of patients with biopsy-proven disease from north-western Spain. Medicine. 2011;90:186-193. doi:10.1097/MD.0b013e31821c4fad

13. Stone JH, Tuckwell K, Dimonaco S, et al. Trial of tocilizumab in giant cell arteritis. $N$ Engl J Med. 2017;377:317-328. doi:10.1056/ NEJMoa1613849

14. Jennette JC, Falk RJ, Bacon PA, et al. 2012 Revised international Chapel Hill consensus conference nomenclature of vasculitides. Arthritis Rheum. 2013;65:1-11. doi:10.1002/art.37715

15. Weyand CM. Younge BR and Goronzy JJ. IFN-gamma and IL-17: the two faces of T-cell pathology in giant cell arteritis. Curr Opin Rheumatol. 2011;23:43-49. doi:10.1097/BOR.0b013e32833ee946

16. Luo J, Wu SJ, Lacy ER, et al. Structural basis for the dual recognition of IL-12 and IL-23 by ustekinumab. J Mol Biol. 2010;402 (5):797-812. doi:10.1016/j.jmb.2010.07.046

17. Conway R, O'Neill L, Gallagher P, et al. Ustekinumab for the treatment of refractory giant cell arteritis. Ann Rheum Dis. 2016;75 (8):1578-1579.

18. Weyand CM, Goronzy JJ. Clinical practice. Giant-cell arteritis and polymyalgia rheumatica. $N$ Engl $J$ Med. 2014;371:50-57. doi:10.1056/NEJMcp1214825

19. Choy E. Clinical significance of Janus Kinase inhibitor selectivity. Rheumatology. 2018;58(6):pp.953-962. doi:10.1093/rheumatology/ key339

20. Dasgupta B, Panayi GS. Interleukin-6 in serum of patients with polymyalgia rheumatica and giant cell arteritis. $\mathrm{Br} J$ Rheumatol. 1990;29:456-458. doi:10.1093/rheumatology/29.6.456

21. Hernandez-Rodriguez J, Segarra M, Vilardell C, et al. Tissue production of pro-inflammatory cytokines (IL-1beta, TNFalpha and IL-6) correlates with the intensity of the systemic inflammatory response and with corticosteroid requirements in giant-cell arteritis. Rheumatology. 2004;43:294-301. doi:10.1093/rheumatology/keh058

22. Weyand CM, Hicok KC, Hunder GG, et al. Tissue cytokine patterns in patients with polymyalgia rheumatica and giant cell arteritis. Ann Intern Med. 1994;121:484-491. doi:10.7326/0003-4819-1217-199410010-00003

23. Koster M, Warrington K. Giant cell arteritis: pathogenic mechanisms and new potential therapeutic targets. BMC Rheumatology. 2017;1:1. doi:10.1186/s41927-017-0004-5

24. Boes CJ. Bayard Horton's clinicopathological description of giant cell (temporal) arteritis. Cephalalgia. 2007;27:68-75. doi:10.1111/ j.1468-2982.2007.01238.x

25. Shick RM, Baggenstoss AH, Fuller BF, et al. Effects of cortisone and ACTH on periarteritis nodosa and cranial arteritis. Proc Staff Meet Mayo Clin. 1950;25:492-494.

26. Maleszewski JJ, Younge BR, Fritzlen JT, et al. Clinical and pathological evolution of giant cell arteritis: a prospective study of follow-up temporal artery biopsies in 40 treated patients. Mod Pathol. 2017;30:788-796. doi:10.1038/modpathol.2017.10

27. Scheurer RA, Harrison AR, Lee MS. Treatment of vision loss in giant cell arteritis. Curr Treat Options Neurol. 2012;14(1):84-92. doi:10.1007/s11940-011-0152-7

28. Hayreh SS, Biousse V. Treatment of acute visual loss in giant cell arteritis: should we prescribe high-dose intravenous steroids or just oral steroids? J Neuroophthalmol. 2012;32(3):278-287. doi:10.1097/ WNO.0b013e3182688218
29. Spiera RF, Mitnick HJ, Kupersmith M, et al. A prospective, double-blind, randomized, placebo controlled trial of methotrexate in the treatment of giant cell arteritis (GCA). Clin Exp Rheumatol. 2001;19:495-501.

30. Jover JA, Hernandez-Garcia C, Morado IC, et al. Combined treatment of giant-cell arteritis with methotrexate and prednisone: a randomized, double-blind, placebo-controlled trial. Ann Intern Med. 2001;134:106-114. doi:10.7326/0003-4819-134-2-200101160-00010

31. Hoffman GS, Cid MC, Hellmann DB, et al. A multicenter, randomized, double-blind, placebo-controlled trial of adjuvant methotrexate treatment for giant cell arteritis. Arthritis Rheum. 2002;46:1309-1318. doi:10.1002/art.10262

32. Mahr AD, Jover JA, Spiera RF, et al. Adjunctive methotrexate for treatment of giant cell arteritis: an individual patient data meta-analysis. Arthritis Rheum. 2007;56:2789-2797. doi:10.1002/art.22754

33. Mackie S, Dejaco C, Appenzeller S, et al. British Society for Rheumatology guideline on diagnosis and treatment of giant cell arteritis. Rheumatology. 2020;59(3):e1-e23. doi:10.1093/rheumatology/kez672

34. Hellmich B, Agueda A, Monti S, et al. Update of the EULAR recommendations for the management of large vessel vasculitis. Ann Rheum Dis. 2020;79:19-30. doi:10.1136/annrheumdis-2019-215672

35. Diamantopoulos AP. Hetland H and Myklebust G. Leflunomide as a corticosteroid-sparing agent in giant cell arteritis and polymyalgia rheumatica: a case series. Biomed Res Int. 2013;2013:120638. doi:10.1155/2013/120638

36. Adizie T, Christidis D, Dharmapaliah C, et al. Efficacy and tolerability of leflunomide in difficult-to-treat polymyalgia rheumatica and giant cell arteritis: a case series. Int J Clin Pract. 2012;66:906-909. doi:10.1111/j.1742-1241.2012.02981.x

37. Loock J, Henes J, Kotter I, et al. Treatment of refractory giant cell arteritis with cyclophosphamide: a retrospective analysis of 35 patients from three centres. Clin Exp Rheumatol. 2012;30:S70-S76.

38. De Boysson H, Boutemy J, Creveuil C, et al. Is there a place for cyclophosphamide in the treatment of giant-cell arteritis? A case series and systematic review. Semin Arthritis Rheum. 2013;43:105-112.

39. Quartuccio L, Maset M, De Maglio G, et al. Role of oral cyclophosphamide in the treatment of giant cell arteritis. Rheumatology. 2012;51:1677-1686. doi:10.1093/rheumatology/kes127

40. Ly KH, Dalmay F, Gondran G, et al. Steroid sparing effect and toxicity of dapsone treatment in giant cell arteritis: a single-center, retrospective study of 70 patients. Medicine. 2016;95:e4974. doi:10.1097/MD.0000000000004974

41. Dospinescu P, Karabayas M, Kidder D, et al. Mycophenolate mofetil versus methotrexate in the management of large vessel giant cell arteritis. Ann Rheum Diseases. 2016;75:798. doi:10.1136/annrheumdis-2016-eular.4330

42. De Silva M, Hazleman BL. Azathioprine in giant cell arteritis/polymyalgia rheumatica: a double-blind study. Ann Rheum Diseases. 1986;45:136-138. doi:10.1136/ard.45.2.136

43. Sailler L, Lapeyre-Mestre M, Geffray L, et al. Adding hydroxychloroquine to prednisone does not improve the outcome in giant cell arteritis: a double blind randomized controlled trial. Arthritis Rheum. 2009;60:1972.

44. Schaufelberger C. No additive effect of cyclosporin A compared with glucocorticoid treatment alone in giant cell arteritis: results of an open, controlled, randomized study. Br J Rheumatol. 1998;37:464-465. doi:10.1093/rheumatology/37.4.464

45. Schaufelberger C, Mollby H, Uddhammar A, et al. No additional steroid-sparing effect of cyclosporine A in giant cell arteritis. Scand $J$ Rheumatol. 2006;35:327-329. doi:10.1080/03009740500474537

46. De Boysson H, Boutemy J, Creveuil C, et al. Is there a place for cyclophosphamide in the treatment of giant-cell arteritis? A case series and systematic review. Semin Arthritis Rheum. 2013;43 (1):105-112. doi:10.1016/j.semarthrit.2012.12.023 
47. Wagner AD, Goronzy JJ, Weyand CM. Functional profile of tissue-infiltrating and circulating CD68+ cells in giant cell arteritis. Evidence for two components of the disease. $J$ Clin Invest. 1994;94:1134-1140. doi:10.1172/JCI117428

48. Garcia-Martinez A, Hernandez-Rodriguez J, Espigol-Frigole G, et al. Clinical relevance of persistently elevated circulating cytokines (tumor necrosis factor alpha and interleukin-6) in the long-term follow-up of patients with giant cell arteritis. Arthritis Care Res. 2010;62:835-841. doi:10.1002/acr.20043

49. Unizony S, Stone JH, Stone JR. New treatment strategies in large-vessel vasculitis. Curr Opin Rheumatol. 2013;25:3-9. doi:10.1097/BOR.0b013e32835b133a

50. O’Neill L, McCormick J, Gao W, et al. Interleukin 6 does not upregulate pro inflammatory cytokine expression in an ex-vivo model of giant cell arteritis. Arthritis Rheumatol. 2014;66:S391.

51. Hernandez-Rodriguez J, Segarra M, Vilardell C, et al. Elevated production of interleukin-6 is associated with a lower incidence of disease related ischemic events in patients with giant-cell arteritis: angiogenic activity of interleukin-6 as a potential protective mechanism. Circulation. 2003;107:2428-2434. doi:10.1161/01.CIR.0000066907.83923.32

52. Villiger PM, Adler S, Kuchen S, et al. Tocilizumab for induction and maintenance of remission in giant cell arteritis: a phase 2, randomised, double-blind, placebo-controlled trial. Lancet. 2016;387:1921-1927. doi:10.1016/S0140-6736(16)00560-2

53. González-Gay MA, Pina T, Prieto-Peña D, Calderon-Goercke M, Blanco R, Castañeda S. Current and emerging diagnosis tools and therapeutics for giant cell arteritis. Expert Rev Clin Immunol. 2018;14:593-605. doi:10.1080/1744666X.2018.1485491

54. Schmidt WA, Dasgupta B, Luqmani R, et al. A multicentre, randomised, double-blind, placebo-controlled, parallel-group study to evaluate the efficacy and safety of sirukumab in the treatment of giant cell arteritis. Rheumatology and Therapy. 2020;7(4):793-810. doi:10. 1007/s40744-020-00227-2

55. Conway R, O'Neill L, McCarthy GM, et al. Interleukin 12 and interleukin 23 play key pathogenic roles in inflammatory and proliferative pathways in giant cell arteritis. Ann Rheum Dis. 2018;77 (12):1815-1824. doi:10.1136/annrheumdis-2018-213488

56. Conway R, O'Neill L, O'Flynn E, et al. Ustekinumab for the treatment of refractory giant cell arteritis. Ann Rheum Dis. 2016;75 (8):1578-1579. doi:10.1136/annrheumdis-2016-209351

57. Conway R, O’Neill L, Gallagher P, et al. Ustekinumab for refractory giant cell arteritis: a prospective 52-week trial. Semin Arthritis Rheum. 2018;48(3):523-528. doi:10.1016/j.semarthrit.2018.04.004

58. Matza MA, Fernandes AD, Stone JH, Unizony SH. Ustekinumab for the treatment of giant cell arteritis published online ahead of print, 2020 Apr 5. Arthritis Care Res. 2020. doi:10.1002/acr.24200

59. Hoffman GS, Cid MC, Rendt-Zagar KE, et al. Infliximab for maintenance of glucocorticosteroid-induced remission of giant cell arteritis: a randomized trial. Ann Intern Med. 2007;146:621-630. doi:10.7326/0003-4819-146-9-200705010-00004

60. Seror R, Baron G, Hachulla E, et al. Adalimumab for steroid sparing in patients with giant-cell arteritis: results of a multicentre randomised controlled trial. Ann Rheum Dis. 2014;73(12):2074-2081. doi:10.1136/annrheumdis-2013-203586

61. Martinez-Taboada VM, Rodriguez-Valverde V, Carreno L, et al. A double-blind placebo-controlled trial of etanercept in patients with giant cell arteritis and corticosteroid side effects. Ann Rheum Dis. 2008;67:625-630. doi:10.1136/ard.2007.082115
62. Langford CA, Cuthbertson D, Ytterberg SR, et al. A randomized, double-blind trial of abatacept (CTLA-4Ig) for the treatment of giant cell arteritis. Arthritis Rheumatol. 2017;69:837-845. doi:10.1002/ art.40044

63. Hartmann B, Liao J, Weisman MH, Warrington KJ, Goronzy JJ, Weyand CM The STAT1 signalling pathway in giant cell arteritis. Meeting: 2013 ACR/ARHP Annual Meeting; San Diego, California, USA; Abstract Number: 1691

64. Zhang H, Watanabe R, Berry GJ, Tian L, Goronzy JJ, Weyand CM. Inhibition of JAK-STAT signalling suppresses pathogenic immune responses in medium and large vessel vasculitis. Circulation. 2018;137:1934-1948. doi:10.1161/CIRCULATIONAHA.117.030423

65. Van der Geest KS, Abdulahad WH, Chalan P, et al. Disturbed B cell homeostasis in newly diagnosed giant cell arteritis and polymyalgia rheumatica. Arthritis Rheumatol. 2014;66:1927-1938. doi:10.1002/ art. 38625

66. Cid MC, Campo E, Ercilla G, et al. Immunohistochemical analysis of lymphoid and macrophage cell subsets and their immunologic activation markers in temporal arteritis. Influence of corticosteroid treatment. Arthritis Rheum. 1989;32:884-893.

67. Alba MA, Prieto-Gonzalez S, Hernandez-Rodriguez J, Cid MC. B lymphocytes may play a significant role in large vessel vasculitis. Future Med. 2012;7:475-477.

68. Bhatia A, Ell PJ, Edwards JC. Anti-CD20 monoclonal antibody (rituximab) as an adjunct in the treatment of giant cell arteritis. Ann Rheum Dis. 2005;64:1099-1100. doi:10.1136/ard.2005.036533

69. Mayrbaeurl B, Hinterreiter M, Burgstaller S, et al. The first case of a patient with neutropenia and giant-cell arteritis treated with rituximab. Clin Rheumatol. 2007;26(9):1597-1598. doi:10.1007/ s10067-007-0684-0

70. Ly KH, Stirnemann J, Liozon E, Michel M, Fain O, Fauchais AL. Interleukin-1 blockade in refractory giant cell arteritis. Joint Bone Spine. 2014;81:76-78. doi:10.1016/j.jbspin.2013.06.004

71. Cid MC, Muralidharan S, Corbera-Bellalta M, et al. FRI0010 GMCSFR pathway is implicated is implicated in pathogenic inflammatory mechanisms in giant cell arteritis. Ann Rheum Dis. 2020;79:576.

72. Burmester GR, McInnes IB, on behalf of the EARTH EXPLORER 1 study investigators, et al. A randomised phase IIb study of mavrilimumab, a novel GM-CSF receptor alpha monoclonal antibody, in the treatment of rheumatoid arthritis. Ann Rheum Dis. 76;2017:1020-1030. doi:10.1136/ annrheumdis-2016-210624

73. Cid M, Unizony S, Pupim L, et al. Mavrilimumab (anti GM-CSF receptor $\alpha$ monoclonal antibody) reduces time to flare and increases sustained remission in a phase 2 trial of patients with giant cell arteritis [abstract]. Arthritis Rheumatol. 2020;72(suppl 10).

74. Rotar Ž, Tomšic M, Hocevar A. Secukinumab for the maintenance of glucocorticoid-free remission in a patient with giant cell arteritis and psoriatic arthritis. Rheumatology. 2018;57:934-936. doi:10.1093/ rheumatology/kex507

75. Sammut L, Litwic A, Smith R, et al. 002 Biopsy proven giant cell arteritis in a patient with psoriatic arthritis on TNF-alpha inhibitor treated with high dose prednisolone and a switch to secukinumab (anti IL-17). Rheumatology. 2018;57(suppl_3):key075.226. doi:10. 1093/rheumatology/key075.226 


\section{Publish your work in this journal}

Biologics: Targets and Therapy is an international, peer-reviewed journal focusing on the patho-physiological rationale for and clinical application of Biologic agents in the management of autoimmune diseases, cancers or other pathologies where a molecular target can be identified. This journal is indexed on PubMed Central, CAS, EMBase,
Scopus and the Elsevier Bibliographic databases. The manuscript management system is completely online and includes a very quick and fair peer-review system, which is all easy to use. Visit http://www.dovepress.com/testimonials.php to read real quotes from published authors.

Submit your manuscript here: https:/www.dovepress.com/biologics-targets-and-therapy-journal 